\title{
EKSPLORASI SEGMENTASI PASAR DAN MOTIVASI WISATAWAN KULINER DI GUDEG PAWON YOGYAKARTA
}

\author{
Ahmadintya Anggit Hanggraito \\ Magister Kajian Pariwisata Universitas gadjah Mada \\ E-mail: datamasanggit@gmail.com \\ Budiani \\ Magister Kajian Pariwisata Universitas gadjah Mada \\ E-mail: Hallodiani@gmail.com
}

\begin{abstract}
Studies on culinary tourists in Yogyakartais rarely explored in depth. In fact, Yogyakarta has become an area with various culinary attractions that have a variety of local foods. Gudeg Pawon is one of the top culinary destinations in Yogyakarta. Through a descriptive method with a qualitative approach, this research explores market segmentation and motivation of culinary tourists in Gudeg Pawon. The results of this study explain that the types of experiencers and enjoyers can represent the market segmentation of culinary tourism in Gudeg Pawon. In addition, there is a structured pattern in showing the main motivating factors for culinary tourists in Gudeg Pawon. Exploration of market segmentation and motivation of culinary tourists can be a deep consideration regarding the management of local food which has great potential in the development of new culinary tourism atractions.
\end{abstract}

Keywords: Culinary Tourism, Market Segmentation, Tourist Motivation, Local Foods

\section{Pendahuluan}

Di Era Globalisasi saat ini, sektor makanan telah menjadi bagian penting saat sesesorang mengunjungi sebuah destinasi. Saat bepergian, orang tidak hanya sekedar makan untuk memuaskan kebutuhan fisik dan fisiologisnya (Henderson, 2014). Makanan dalam sebuah destinasi wisata berpotensi meningkatkan pengalaman pengunjung, hal ini memungkinkan mereka untuk Terhubung dengan tempat, budayanya, dan warisannya; menjadi pengalaman dari pengunjung; dan berkontribusi dalam pembangunan konsep yang lebih besar dari keaslian objek 
wisata itu sendiri (Sims, 2009; Kim \& Eves, 2012; Ellis dkk, 2018; Castillo-Canalejo, dkk, 2020). Hal ini menjelaskan bahwa, optimalisasi pemasaran produk makanan lokal di sebuah destinasi dapat menjadi strategi penting destinasi dalam mendatangkan wisatawan.

UNWTO (2017) menyatakan bahwa diperkirakan 30\% dari pendapatan pariwisata bersumber dari wisata kuliner atau gastronomi (Leewellyn \& Abdillah, 2020). Wisata kuliner adalah ceruk yang bertumbuh dalam industri, sehingga diperkirakan akan semakin lebih kuat karena lebih banyak penyedia dan wisatawan menyadarinya (Long, 2013). Indonesia melalui Kementerian Pariwisata mempromosikan kuliner lokal khas nusantara dalam ajang $5^{\text {th }}$ United Nation World Tourism Organization (UNWTO) World Forum on Gastronomy Tourism 2019 yang berlangsung di San Sebastian, Spanyol pada 2-3 Mei 2019 (Sakti, 2019). Vita Datau Ketua Tim Percepatan dan Pengembangan Wisata Kuliner dan Belanja Kementerian Pariwisata menyebutkan bahwa, destinasi wisata kuliner menjadi fokus pemerintah di tiga wilayah, yaitu Bali, Joglosemar (Jogjakarta, Solo, Semarang), dan Bandung (Reily, 2019). Dalam hal ini, DI Yogyakarta memiliki potensi besar sebagai salah satu kawasan potensial yang strategis dalam pengembangan wisata kuliner.

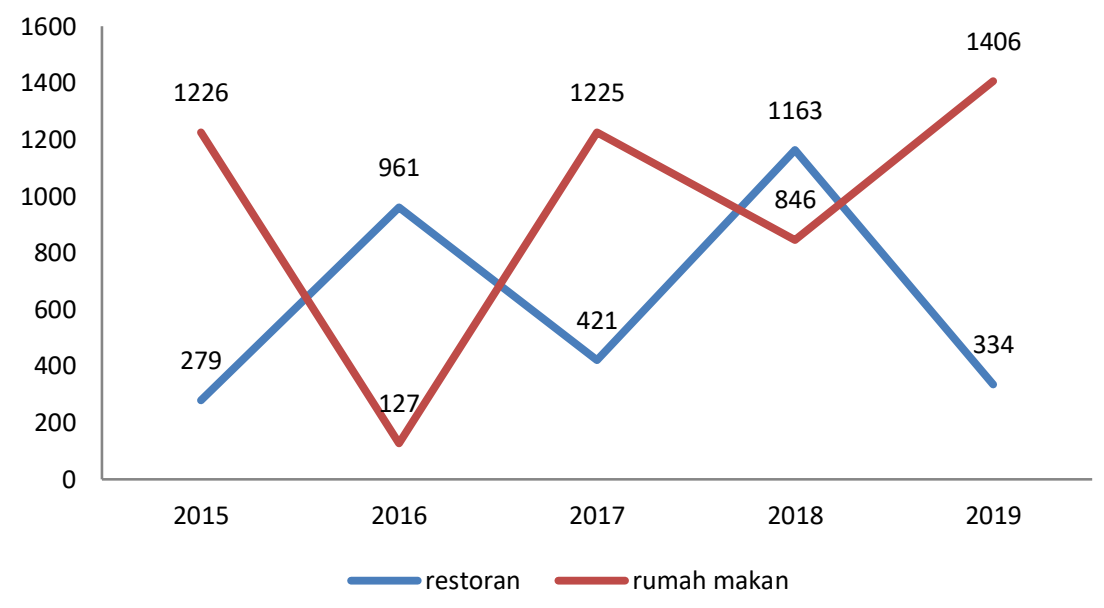

Gambar 1. Grafik pertumbuhan Restoran Rumah Makan di Provinsi DI Yogyakarta Sumber: Provinsi Daerah Istimewa Yogyakarta dalam Angka, 2020 
Gambar 1 menjelaskan bahwa, restoran dan rumah makan yang selama ini menjadi fasilitator wisata kuliner di DI Yogyakarta mengalami pertumbuhan yang fluktuatif. Di sisi lain, pertumbuhan jumlah pengunjung objek wisata dari tahun 2018 ke tahun 2019 sebesar 2.181.569 orang, dengan rincian total 1.008.599 wisatawan mancanegara, dan 27.688.758 orang wisatawan nusantara pada tahun 2019 (Provinsi Daerah Istimewa Yogyakarta dalam Angka, 2020). Ditambahkan pula bahwa, Ratarata pengeluaran per kapita penduduk pada tahun 2019 tercatat sebesar Rp 1.339.726 per kapita per bulan. Jumlah tersebut terdiri dari pengeluaran makanan sebesar $40,79 \%$ dari seluruh pengeluaran. Oleh karena itu, pengembangan yang tepat pada makanan lokal akan mampu memberikan pilihan yang variatif bagi wisatawan yang berkunjung ke DI Yogyakarta

Provinsi DI Yogyakarta memiliki berbagai rekomendasi makanan lokal yang mampu menarik wisatawan, salah satunya adalah Gudeg. Gudeg mampu menjadi makanan lokal yang memiliki khas tersendiri di DI Yogyakarta. Menurut Nurindiani (2016),

“sejak status 'khas Yogyakarta' dan 'ikon' yang dilekatkan pada masakan gudeg, gudeg pun memiliki fungsi baru, yaitu gudeg sebagai identitas. Keberadaan gudeg dimunculkan sebagai salah satu makanan yang dapat mempresentasikan kewilayahan dan identitas melalui sejarahnya, sekaligus menghormati tamu dengan predikat ikonik yang dimiliki gudeg. Meski bukan makanan ritual, pada banyak acara dengan tamu undangan dari luar kota, gudeg menjadi salah satu hidangan yang (seakan) wajib disajikan." (Nurindiani, 2016).

Salah satu sajian Gudeg yang menjadi salah satu 10 top destinasi kuliner DI Yogyakarta adalah Gudeg Pawon (Dispar, 2019). Bagian menarik dari Gudeg Pawon adalah konsepnya yang menggunakan pawon atau dapur sebagai tempat mengambil makanan (hazmi, 2017). Pengelolaan Gudeg Pawon sebagai sebuah tempat makan menunjukkan bahwa, makanan lokal dapat dilestarikan dengan tepat guna, sehingga 
akan mampu menunjukkan gambaran segmentasi pasar untuk wisatawan kuliner. Segmentasi pasar untuk wisatawan kuliner menunjukkan hubungan kuat antara sikap dan perilaku, serta pengalaman terkait destinasi itu sendiri (Yun, dkk, 2011). Selain itu, wisata yang mengedepankan makanan sebagai tujuan utama dapat ditunjukkan oleh tiga faktor utama motivasi dari wisatawan seperti, pengalaman dan kebaruan makanan; hedonisme dan waktu luang; dan hubungan pengalaman dengan pekerjaan (Castillo-Canalejo, dkk, 2020). Mengacu pernyataan tersebut, Penulis bertujuan untuk mengeksplorasi segmentasi pasar dan faktor motivasi wisatawan kuliner di Gudeg Pawon dengan pendekatan kuantitatif. Studi ini diharapkan menjadi masukan bagi pengelolaan makanan lokal dalam kaitannya pengembangan wisata kuliner di DI Yogyakarta.

\section{Tinjauan Pustaka}

\section{Wisata Kuliner dan Makanan Lokal}

Aktivitas berwisata yang bersentuhan dengan makanan terklasifikasikan dalam beberapa istilah yakni, food tourism, culinary tourism, atau Gastronomy tourism (Karim \& Chi, 2010). Lucy Long mengistilahkan wisata kuliner pada tahun 1998 adalah untuk mengekspresikan gagasan tentang bagaimana kita merasakan budaya melalui makanan (Wolf, 2004). Wisata kuliner adalah sarana mencari pengalaman dan berpartisipasi terkait makanan dari orang lain, yang mana tidak sebatas mengkonsumsi, pengolahan, dan presentasi dari makanan. (Long, 2004). Keterkaitan dengan pariwisata berkelanjutan yakni, Wisata kuliner menjadi daya tarik kuat dan mampu meningkatkan kesejahteraan penduduk setempat (Wijayanti, 2020). Hal ini yang menjelaskan bahwa, keberlanjutan dari gudeg pawon sebagai sebuah wisata kuliner telah mampu memberikan multiple effect dalam kepariwisataan. 
Secara umum, Makanan lokal menurut Sims (2009) merupakan makanan yang menggambarkan keaslian, ia berpendapat bahwa permintaan konsumen untuk makanan yang di-anggap "tradisional" dan "lokal" juga dapat dilihat sebagai terkait dengan pencarian keaslian. Keunikan makanan lokal sangat terkait dengan daerah setempat, dan dikarenakan hal itu ialah bagian dari budaya lokal dan sejarahnya yang melekat dari sistem sosial, ekonomi, dan lingkungan (Björk dan Kauppinen-Räisänen, 2016). Allen \& Hinrichs (2007) berpendapat bahwa wisatawan cenderung mengasosiasikan makanan lokal dengan produk khusus tertentu (makanan dan minuman yang berhubungan dengan daerah tersebut). Berdasarkan pernyataanpernyataan di atas, Gudeg sebagai bagian dari makanan lokal merupakan salah satu sajian makanan yang memiliki keterikatan dengan kehidupan sosial dan kebudayaan dari sebuah kawasan tertentu.

\section{Segmentasi Pasar Wisata Kuliner}

Faktanya, Gudeg Pawon merupakan sebuah destinasi yang menyediakan makanan lokal yang otentik, waktu yang terstruktur, dan lokasi yang spesifik. Hal ini menunjukkan bahwa, Gudeg Pawon secara tidak langsung telah memiliki segmentasi pasar untuk wisatawan kuliner. Terdapat banyak tipe wisatawan pecinta makanan dengan beragam demografi sosial, minat aktivitas makanan, dan preferensi makan (Kline dkk., 2018). Menurut Assauri (2015), Segmentasi pasar dimaksud sebagai kegiatan membagi suatu pasar ke dalam kelompok-kelompok yang berbeda. Proses ini menjadi sebuah keharusan dalam berbagai pola strategi pemasaran destinasi wisata. Segmentasi pasar tidak lain adalah suatu usaha untuk mengelompokkan konsumen dalam beberapa kelompok yang secara relatif orang-orangnya cukup homogen (Yoety, 2002). Penelitian mengenai segmentasi pasar wisata kuliner membutuhkan pemaparan mengenai beberapa segmen penting. Segmentasi Sociodemografis memungkinkan penelitian dalam variabel sosial ekonomi dan demografi sebagai penentu dalam budaya mengkonsumsi makanan (Mak, dkk, 2012). 
Sedangkan, segementasi psikografis membagi kelompok berdasarkan gaya hidup atau kepribadian atau nilai. Orang-orang dalam kelompok demografis yang sama dapat menunjukkan gambaran psikografis yang sangat berbeda (Kotler, 2007). Dalam penelitian ini, penulis berfokus untuk mengidentifikasi segmen wisatawan kuliner di Gudeg pawon dalam, segmen socio-demografis, dan Psikografis.

Segmentasi Socio-demografis yang terkait dengan wisata kuliner dipaparkan dalam variabel-variabel seperti usia, jenis kelamin, pendidikan, pendapatan, status pernikahan, agama, dan Generasi (Cho, dkk, 2017). Variabel sosial-demografis umumnya digunakan untuk memprediksi pola konsumsi makanan (Papela dan O'Halloran, 2014). Hal itu menjelaskan pilihan makanan seseorang, cara penyajian, disajikan dan dimakan, berbicara banyak tentang siapa seseorang dan posisi seseorang dalam suatu kelompok (Richards, 2005). Segmentasi ini dapat berfungsi sebagai prediktor profil wisatawan yang mengunjungi sebuah destinasi wisata kuliner.

Setiap wisatawan mencari destinasi yang melibatkan kegiatan gastronomi saat mereka bepergian jauh dari rumah (Daries, dkk., 2018). Oleh karena itu, perlu identifikasi terhadap segmen psikografis wisatawan dari sebuah wisata kuliner. Psikografi sering diartikan sebagai pengukuran AIO (Activity, Interest, Opinion), yakni pengukuran kegiatan, minat dan pendapat konsumen (Kotler, 2007). Sikap wisatawan terkait makanan dapat menjadi model pengklasifikasian tersendiri untuk segmen wisatawan kuliner. Björk dan Kauppinen-Räisänen (2016) menjelaskan bahwa, wisatawan kuliner dapat dibedakan melalui sikap mereka terhadap makanan lokal dan pasar makanan lokal dimana hal ini berdampak terhadap perilaku yang terkait dengan makanan, seperti pengalaman yang terkait makanan. 
Pengalaman terkait makanan menurut Björk dan Kauppinen-Räisänen (2016) dapat dilihat dari; budaya makanan lokal, makanan homemade, kebaruan dari makanan, otentiitas makanan, makanan lokal, keaslian makanan, kesehatan makanan, keunikan makanan, keikutsertaan dalam preparasi makanan, well-known food, Dining companionship, estetika makanan, memilih makan di restoran, lingkungan restoran, Atmosfer/suasana restoran, dan tingkat kehilangan stress. Aspek-aspek tersebut dapat diidentifikasi sebagai indikator penunjang dari tipe-tipe psikografis wisatawan yang berkunjung ke sebuah destinasi kuliner. Segmen Psikografis wisatawan kuliner dapat dijabarkan dalam tiga tipe yakni, Experiencer, yang menganggap makanan penting untuk pemilihan destinasi; Enjoyers, yang memiliki sikap positif terhadap makanan; dan Survivors, yang menganggap bahwa makanan lokal tujuan mereka mencakup kebutuhan fisiologis (Björk dan Kauppinen-Räisänen, 2016). Ditambahkan bahwa, Semakin tinggi tingkat keterkaitan item pengalaman terhadap makanan maka dapat dimasukkan ke dalam kategori Experiencer. Hal ini dapat dijadikan acuan dalam mengklasifikasi tipe wisatawan kuliner melalui pengalaman atas aktivitas yang terkait makanan.

\section{Motivasi Wisatawan Kuliner}

Selanjutnya, Identifikasi faktor motivasi dari wisatawan kuliner bertujuan untuk mendapatkan pola strategi yang tepat dari Gudeg Pawon ke depannya. Motivasi mengunjungi destinasi yang menjadikan makanan sebagai tujuan utama, dijelaskan oleh Castillo-Canalejo, dkk (2020) dalam tiga faktor, yakni:

1. Pengalaman dan kebaruan makanan, yang terdiri atas: pengalaman makanan dan minum baru; merasakan sajian favorit; Hasrat mencoba sesuatu yang baru; Relaksasi dan melepaskan diri dari kegiatan rutin sehari-hari; dan Reputasi bagus dari tempat makan. 
2. hedonisme dan waktu luang, yang terdiri atas: bersantai bersama relasi dan teman-teman; aktivitas bersenang-senang (leisure); dan antara kualitas dan harga berkesinambungan.

3. berhubungan dengan pengalaman pada pekerjaan, yang terdiri atas: pertemuan kerja; dan mengembangkan peluang untuk berjejaring

Identifikasi terhadap segmentasi pasar dan faktor motivasi wisatawan kuliner diharapkan dapat memberikan bahan pertimbangan terkait pengembangan berkelanjutan wisata kuliner di sebuah daerah. Pepela \& O'Halloran, (2014) menjelaskan bahwa, bagian dari asosiasi restoran, agen pariwisata, dan perhotelan, ditambah organisasi pemasaran produk seperti asosiasi produsen semuanya menjadi pilar penting dalam mengembangkan makanan sebagai daya tarik pariwisata yang dapat menguntungkan suatu kawasan (Wijayanti, 2020). Oleh karena itu, hal ini menjadi penting dalam keberlanjutan sebuah destinasi wisata kuliner.

\section{Metode Penelitian}

Jenis penelitian ini meruapakan penelitian studi kasus dengan pendekatan kualitatif. Teegavarapu, Summers dan Mocko (2008), studi kasus dapat dilakukan dengan berbagai tujuan, seperti menggambarkan suatu fenomena, menguji teori atau menghasilkan teori. Penelitian kualitatif berupaya memahami bagaiman seorang individu melihat, memaknai, atau menggambarkan dunia sosialnya (Sudaryono, 2019). Pengumpulan data melalui survei, wawancara mendalam dan pengamatan langsung. Data kuantitatif berasal dari hasil kuesioner, sedangkan data kualitatif berasal dari pengamatan langsung dan wawancara secara mendalam kepada pengelola dan wisatawan yang berkunjung ke Gudeg Pawon. 
Penelitian ini menggunakan teknik purposive sampling dimana pemilihan sampel bertitik tolak pada penelitian pribadi peneliti yang menyatakan sampel yang dipilih benar-benar representatif (Sudaryono, 2019). Sampel dalam penelitian ini adalah responden yang pernah mengunjungi dan menikmati makanan di Gudeg Pawon. Berdasarkan Provinsi Daerah Istimewa Yogyakarta dalam Angka (2020), pada tahun 2019 Jumlah populasi dari wisatawan adalah 28.697.357 orang dan penduduk dari DI Yogyakarta adalah 3.842.932 orang, atau dengan kata lain total populasi berjumlah 32.540.289 orang. Dalam penelitian ini, penentuan besaran jumlah sampel menggunakan rumus slovin yang dikemukakan oleh Umar (2013) yaitu :

$$
s=\frac{N}{1+N e^{2}}
$$

Gambar 2. Rumus Slovin

Sumber: Umar (2013)

Berikut perhitungan untuk rumus Slovin untuk sampel dalam penelitian ini.

$$
s=\frac{32540289}{1+32540289(0.1)^{2}}=99.99
$$

\section{Keterangan:}

$\begin{array}{lll}\mathrm{S} & = & \text { sampel } \\ \mathrm{N} & = & \text { populasi } \\ \mathrm{e} & = & \text { derajat ketelitian }\end{array}$

Berdasarkan rumus Slovin di atas, sampel yang digunakan dalam penelitian ini dibulatkan menjadi sebanyak 100 responden.

Kuesioner dalam penelitian ini menggunakan skala likert, dimana fungsinya adalah untuk mengukur tingkat setuju atau tidak setuju atas pernyataan tertentu (Pimentel, 2019). skor item jawaban yang digunakan yakni, sangat setuju (4); setuju dengan (3); tidak setuju (2); dan sangat tidak setuju (1). Dalam penilaian skala likert angka 1 hingga 4 terdapat interval yang diklasifikasikan dalam pengungkapan makna 
tertentu pada segmentasi pasar dan faktor motivasi. Skala interval ialah skala yang mempunyai rentangan konstan antara tingkat satu dengan yang aslinya, tetapi tidak mempunyai angka 0 mutlak (Irianto, 2004).

Untuk segmentasi pasar terdapat tipe-tipe wisatawan yang ingin diungkap. Untuk tipe Experiencers berada di interval nilai 3-4, Enjoyers berada di interval nilai 23, dan Survivors berada di interval nilai 1-2. Tipe Experiencer dijelaskan sebagai tipe yang memiliki interaksi tinggi terhadap AIO yang teridentifikasi dalam berbagai indikator pengalaman terkait makanan. Sedangkan, untuk melihat faktor utama motivasi wisatawan terdapat berbagai indikator yang berada pada, pengalaman dan kebaruan makanan; hedonisme dan waktu luang; dan pengalaman pada pekerjaan. Skala interval digunakan untuk melihat berbagai indikator yang paling disepakati oleh responden sebagai motivasi berkunjung.

Data diolah melalui analisis statistik deskriptif, dengan menggunakan SPSS 17.0. Statistik deskriptif menggambarkan tentang ringkasan data-data penelitian seperti mean, standar deviasi, varian, modus (Soecahyadi, 2012). Nilai Mean dijadikan penilaian deskripsi statistik responden terkait segmentasi pasar dan faktor motivasi wisatawan kuliner. Untuk mencari kesimpulan berikut tahapan data terkait segmentasi pasar dan motivasi wisatawan di Gudeg Pawon yang menganut model Milles dan Huberman (2003) dalam Ayustina (2019), yaitu:

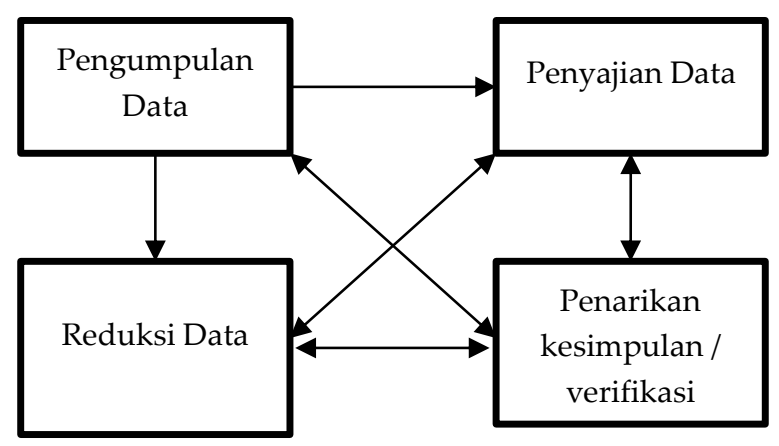

Gambar 2. Model Interaktif Analisa Data

Sumber: Milles dan Huberman (2003) dalam Ayustina (2019) 
1. Reduksi Data. Reduksi data terjadi terus menerus selama analisis. Pertama, pengeditan, segmentasi, dan peringkasan data yang sudah dikumpulkan. Kemudian, pengkodean dan pemaknaan, serta mengasoasikan aktivitas dengan pola tertentu. Terakhir, proses konseptualisasi dan pemaparan, dimana pengembangan konsep abstrak bagian dari reduksi data.

2. Penyajian Data. Tahap ini memberikan ringkasan deskriptif dan sistematis agar dapat mengetahui ide pokok dengan mudah dan menafsirkannya secara kritis.

3. Penarikan Kesimpulan atau Verifikasi. Penarikan kesimpulan secara logis mengikuti reduksi dan penyajian data. kesimpulan yang mungkin bisa dicatat dan perlu diverifikasi.

\section{Pembahasan}

\section{Gudeg Pawon}

Secara umum, Gudeg Pawon memiliki sejarah panjang yang berawal dari Ibu dari Pak Wanto (pemilik usaha) membuka usaha gudeg di Pasar Sentul Jalan Sultan Agung pada tahun 1958. Nama Gudeg Pawon bukan diberikan oleh Pak Wanto selaku pemilik usaha gudeg melainkan oleh pelanggan gudeg yang sering datang. Lokasi Gudeg Pawon berada di Jl. Janturan UH/IV No. 36, Warungboto, Umbulharjo, Warungboto, Umbulharjo, Kota Yogyakarta, DI Yogyakarta. Gudeg Pawon mulai membuka pintu dapurnya dan siap melayani pelanggan pada pukul 22.00 hingga pukul 23.30 malam hari. Akan tetapi karena pelanggan yang sudah berdatangan dari pukul 21.00 maka pintu dapur akan dibuka setengah jam lebih awal dari jam operasional. 


\section{Segmentasi Socio-Demografis Wisatawan Kuliner Gudeg Pawon}

Tabel 1. Statistik Socio-Demografis Wisatawan Gudeg Pawon

\begin{tabular}{|c|c|c|c|c|}
\hline Variabel & Kategori & Total & Pria & Wanita \\
\hline Gender & & 100 & 52 & 48 \\
\hline \multirow[t]{5}{*}{ Usia } & $<20$ tahun & 1 & 1 & - \\
\hline & 21-30 tahun & 66 & 29 & 37 \\
\hline & 31-40 tahun & 21 & 16 & 5 \\
\hline & 41-50 tahun & 7 & 4 & 3 \\
\hline & $>50$ tahun & 5 & 2 & 3 \\
\hline \multirow{3}{*}{$\begin{array}{l}\text { Asal } \\
\text { Daerah }\end{array}$} & Asli Yogyakarta & 23 & 12 & 11 \\
\hline & $\begin{array}{l}\text { Luar DI Yogyakarta (masih } \\
\text { berada di pulau Jawa }\end{array}$ & 59 & 33 & 26 \\
\hline & Berada di luar pulau Jawa & 18 & 8 & 10 \\
\hline \multirow[t]{5}{*}{ Pendidikan } & SD/SMP/SMA & 7 & 4 & 3 \\
\hline & Vokasi & 1 & 1 & 0 \\
\hline & Sarjana (S1) & 56 & 37 & 29 \\
\hline & Pascasarjana (S2) & 35 & 20 & 15 \\
\hline & Doctor (S3 & 1 & 1 & 0 \\
\hline \multirow{3}{*}{$\begin{array}{l}\text { Intensitas } \\
\text { kunjungan }\end{array}$} & 1 kali & 31 & 18 & 13 \\
\hline & 2-3 kali & 42 & 19 & 23 \\
\hline & >3 kali & 27 & 15 & 12 \\
\hline
\end{tabular}

Sumber : Peneliti (2020)

Berdasarkan 247 responden yang menerima kuesioner melalui google-form yang terdapat 171 orang responden yang merespon. Hasil survei menunjukkan 100 responden yang berkunjung ke Gudeg Pawon diantaranya adalah 52 pria dan 48 wanita. Deskripsi statistik socio-demografis wisatawan yang pernah mengunjungi Gudeg Pawon menunjukkan bahwa, sekitar $69 \%$ responden pernah lebih dari satu kali mengunjungi gudeg pawon. Gudeg Pawon telah memiliki konsumen yang 
berada di luar DI Yogyakarta. Hal ini ditunjukkan dengan $77 \%$ responden mengaku bukan penduduk asli DI Yogyakarta. Pada indikator lain ditemukan bahwa, usia mayoritas pengunjung jarang berusia di atas 40 tahun. Hal ini menunjukkan bahwa, pengunjung dari gudeg pawon didominasi oleh usia muda.

\section{Segmentasi Psikografis Wisatawan Kuliner Gudeg Pawon}

Tabel 2. Psikografis wisatawan atas pengalaman terkait makanan di Gudeg Pawon

\begin{tabular}{lll} 
Indikator & Mean & Index (\%) \\
\hline budaya makanan lokal & 3,45 & 0,86 \\
makanan homemade & 3,57 & 0,89 \\
kebaruan makanan & 2,66 & 0,67 \\
otentiitas makanan & 3,32 & 0,83 \\
Makanan lokal & 3,69 & 0,92 \\
keaslian makanan & 3,57 & 0,89 \\
kesehatan makanan & 3,04 & 0,76 \\
keunikan makanan & 3,09 & 0,77 \\
keikutsertaan dalam preparasi makanan & 3,56 & 0,89 \\
well-known food & 3,01 & 0,75 \\
Dining companionship & 3,21 & 0,80 \\
estetika makanan & 2,92 & 0,73 \\
memilih makan di restoran & 3,35 & 0,84 \\
lingkungan restoran & 2,77 & 0,69 \\
Atmosfer restoran & 2,90 & 0,73 \\
tingkat kehilangan stress & 2,72 & 0,68 \\
\hline Rata-rata & 3,18 & 0,79 \\
\hline & & \\
\hline & 3,65 & \\
\hline
\end{tabular}

Sumber : Peneliti (2020) 
Tabel 2 menunjukkan prosentase kesepakatan responden terhadap indikator pengalaman terkait makanan di destinasi yang menggambarkan psikografis wisatawan di Gudeg Pawon. Rataan Index sebesar 79\% menunjukkan tingkat pengalaman terkait makanan yang dialami responden di Gudeg Pawon. Pengalaman terhadap makanan menjelaskan berbagai macam tipe psikografis dari wisatawan. Hasil survei menunjukkan bahwa, terdapat dua tipe utama wisatawan kuliner di Gudeg Pawon, yakni Experiencers dan Enjoyers.

Tipe Experiencers menunjukkan bahwa, responden merupakan tipe wisatawan yang ingin mendapatkan pengalaman terkait makanan di destinasi tersebut. Hasil survei menunjukkan bahwa tipe Experiencers di gudeg pawon memiliki pengalaman tinggi terkait ketertarikan tinggi terhadap budaya makanan lokal $(3,45)$, makanan homemade $(3,57)$, otentiitas makanan $(3,32)$, Makanan lokal $(3,69)$, keaslian makanan $(3,57)$, kesehatan makanan $(3,04)$, keunikan makanan $(3,09)$, keikutsertaan dalam preparasi makanan $(3,56)$, well-known food $(3,01)$, Dining companionship $(3,21)$, dan model memilih makan di restoran $(3,35)$. Keaslian makanan dan makanan homemade menjadi rataan tertinggi dalam tipe Experiencers. Tipe ini merupakan tipe wisatawan yang berpilkir terbuka dalam merasakan berbagai jenis makanan yang berbeda (Björk dan Kauppinen-Räisänen, 2016). Selain itu, ditambahkan juga bahwa, tipe ini juga menilai pada keaslian, kelokalan, otentitas, dan keunikan dari makanan sehingga berpeluang untuk memuaskan wisatawan.

Sedangkan, tipe lainnya sebagai Enjoyers. Tipe Enjoyers merupakan wisatawan yang tidak memiliki motif tinggi terhadap makanan sebagai tujuan, namun hanya memiliki sikap positif terhadap makanan (Björk dan Kauppinen-Räisänen, 2016). Hasil penelitian ini menunjukkan bahwa, Tipe Enjoyers di Gudeg Pawon memiliki sikap positif terhadap beberapa hal seperti, kebaruan makanan $(2,66)$, estetika makanan (2,92), lingkungan restoran $(2,77)$, Atmosfer restoran $(2,90)$, dan tingkat kehilangan stress (2,72). Enjoyers dijelaskan hasil survei sebagai penikmat estetika 
pada makanan dan atmosfer dari gudeg pawon. Björk dan Kauppinen-Räisänen (2016) menjelaskan bahwa, tipe Enjoyers tidak memilih makanan sebagai sesuatu yang penting dalam memilih tempat, atau sebagai tempat liburan. Oleh karena itu, Enjoyers dapat dijelaskan sebagai tipe wisatawan yang beraktivitas cenderung bersantai atau berrelaksasi di gudeg pawon.

Berdasarkan hasil wawancara mendalam, terdapat berbagai indikator dalam aspek psikografis dari responden yang berkaitan langsung dengan makanan dari sebuah destinasi wisata kuliner. Wisatawan bertipe Experiencers, menunjukkan minat yang besar dalam mendapatkan pengalaman lebih dari destinasi yang akan dituju. Salah satunya dalam indikator makanan homemade, otentisitas, keaslian makanan, dan ketertarikan pada makanan lokal itu sendiri. Dalam sebuah pernyataan oleh salah satu wisatawan,

“Enak makan di Gudeg Pawon karena nasi nya masih panas, beda sama penjual gudeg lain yang terasa dingin. Kalau Gudeg Pawon hangat enak." (Sinta, Yogyakarta, 2019)

Selain itu terdapat pendapat lain yakni,

“aroma kayu bakarnya khas jadi nambah nafsu makan” (Roy, Semarang, 2019).

Segmentasi pasar Gudeg Pawon mampu menjelaskan berbagai tipe wisatawan yang berfokus pada makanan lokal dalam sebuah destinasi kuliner. Segmentasi SocioDemografis dan psikografis seseorang menunjukkan peran makanan lokal sebagai poin penting atas terbangunnya keterikatan wisatawan dengan destinasi wisata kuliner. 
Motivasi Wisatawan Kuliner Gudeg Pawon

Tabel 3. Motivasi Wisatawan Gudeg Pawon

\begin{tabular}{|c|c|c|}
\hline Indikator & Mean & St. Deviasi \\
\hline \multicolumn{3}{|l|}{ Pengalaman dan kebaruan makanan } \\
\hline pengalaman makanan \& minum baru & 3,33 & 0,711 \\
\hline merasakan sajian favorit & 3,39 & 0,69 \\
\hline $\begin{array}{l}\text { Hasrat untuk mencoba sesuatu hal yang } \\
\text { baru. }\end{array}$ & 3,41 & 0,77 \\
\hline $\begin{array}{l}\text { Relaksasi dan melepaskan diri dari kegiatan } \\
\text { rutin sehari-hari. }\end{array}$ & 2,77 & 0,89 \\
\hline Reputasi bagus dari tempat makan. & 3,2 & 0,81 \\
\hline \multicolumn{3}{|l|}{ hedonisme dan waktu luang } \\
\hline bersantai bersama relasi \& teman-teman & 2,89 & 0,82 \\
\hline aktivitas bersenang-senang (leisure) & 2,89 & 0,89 \\
\hline kesinambungan antara kualitas \& harga. & 3,05 & 0,78 \\
\hline \multicolumn{3}{|c|}{ berhubungan dengan pengalaman pada pekerjaan } \\
\hline pertemuan kerja & 1,86 & 0,88 \\
\hline mengembangkan peluang untuk berjejaring & 2,05 & 0,88 \\
\hline Rataan & 2.88 & 0.81 \\
\hline
\end{tabular}

Sumber : Peneliti (2020)

Tabel 3 menunjukkan berbagai macam motivasi responden yang mengunjungi gudeg pawon. Terdapat tiga faktor motivasi yang terkait dengan makanan (CastilloCanalejo, dkk, 2020). Dalam penelitian ini, motivasi utama mengunjungi gudeg pawon adalah motivasi pengalaman dan kebaruan makanan. Dimana wisatawan mencari pengalaman dan kebaruan makanan dengan indikator: pengalaman makanan \& minum baru (3,33); merasakan sajian favorit (3,39); Hasrat untuk mencoba sesuatu hal yang baru $(3,41)$; dan Reputasi bagus dari tempat makan $(3,2)$. Adanya 
konsumen setia yang berasal dari luar kota membuktikan bahwa, indikator yang menunjang pengalaman kuliner terhubung dengan motivasi wisatawan.

Berdasarkan hasil wawancara langsung terhadap pengunjung dari Ubud, Bali (2019) menjelaskan bahwa, ketika sampai lokasi Gudeg Pawon langsung beliau diberitahu oleh juru parkir bahwa persediaan sudah habis. Keluarga pengunjung yang berjumlah tujuh orang ini tidak pantang menyerah dan tetap mengantre walau sudah diberitahu situasinya. Keluarga dari Ubud Bali tersebut menganggap ingin menguji keberuntungan mereka. Apabila ketika sampai di depan penjual menu benar-benar habis, maka tidak menganggap itu sebagai masalah. Menurut beliau sensasi mengantre malam hari di sebuah gang kecil dan dapur adalah pengalaman yang tidak bisa dilupakan pada saat berwisata ke DI Yogyakarta.

"Hoki-hokian aja mba, padahal tadi udah dibilang habis sama tukang parkirnya, tapi penasaran aja, siapa tau beruntung masih ada." (Pak Ketut, 2019)

Selain itu, merasakan sajian favorit menjadi salah satu motivasi tersendiri bagi wisatawan kuliner Gudeg Pawon.

“kalau ke Jogja belum ke Gudeg Pawon, seperti makan nasi tanpa garam, hambar dan tidak lengkap." (Roy, Semarang, 2019)

Kemudian faktor hedonisme dan waktu luang. Dimana wisatawan pada faktor hedonisme dan waktu luang dipengaruhi oleh adanya indikator kesinambungan antara kualitas dan harga $(3,05)$ dari gudeg pawon. Kelima indikator ini dikatakan sebagai pemicu motivasi utama wisatawan kuliner di gudeg pawon. Di sisi lain, indikator yang bernilai rendah terkait motivasi adalah untuk melakukan pertemuan kerja $(1,89)$. 


\section{Eksplorasi Segmentasi Pasar dan Motivasi Wisatawan dalam pengelolaan wisata Kuliner Gudeg Pawon.}

Studi terkait Gudeg Pawon menunjukkan eksplorasi sebuah intisari yang berkesinambungan. Wisatawan kuliner Gudeg Pawon menunjukkan hubungan kuat antara persepsi dengan berbagai indikator yang menunjang makanan lokal. Tipe Experiencers berfokus pada keaslian, kelokalan, otentitas, dan keunikan dari makanan. Tipe ini menggerakkan kekuatan dari karakteristik gudeg sebagai makanan lokal. Rasa gurih dari sajian Gudeg Pawon inilah yang menjadi salah satu daya tarik gudeg ini begitu diminati oleh orang luar Yogyakarta; Tipe Enjoyers berfokus estetika pada makanan dan atmosfer dari gudeg pawon. Estetika makanan dan Atmosfer dari Gudeg Pawon didukung dengan budaya penyajian dan pelayanan yang dirasakan, serta suasana dari dapur atau pawon yang menjadi salah satu daya tarik utama di Gudeg Pawon. Wujud dapur khas di Jawa dengan segala aktivitasnya yang merupakan sebuah modal kultural dimanfaatkan demi menjadi daya tarik pengunjung; dan Gudeg Pawon diminati karena memberikan sensasi seolah makan di dapur tradisional.

Makanan lokal, modal kultural, serta atmosfer yang ada di Gudeg Pawon merupakan sebuah otentitas yang mampu menjadi aspek penting dari sebuah kepariwisataan kuliner. Sensasi menikmati makanan lokal di tempat dengan modal kultural dapat memberikan motivasi tersendiri bagi wisatawan. Sense of place didasarkan pada hubungan antara orang-orang dalam lingkungan yang diciptakan melalui berbagai pengalaman (Campelo, dkk, 2013). Karakter sensasi tempat dapat memotivasi seseorang untuk mengunjungi gudeg pawon. Hal ini tentunya dapat menja 'di pertimbangan strategi promosi dan branding bagi gudeg pawon sehingga mampu bertahan hingga saat ini. 
Selain hal itu, terdapat prinsip penting yang dijaga dalam pengelolaan dari Gudeg Pawon. Pertama, Pak Wanto yang mewarisi usaha Gudeg Pawon ini mengelola dengan mengedepankan nilai-nilai yang diwasiatkan ibu nya untuk terus dilaksanakan. Nilai yang diturunkan ibunya adalah agar terus menjaga nilai kekeluargaan dengan pelanggan, dan menjaga rasa. Kedua, meskipun Gudeg Pawon sudah terkenal, harga tetap terjangkau bagi mahasiswa dan lingkungan sekitar. Kedekatan dengan pelanggan juga sangat terasa saat Pak Wanto, istrinya, dan adik perempuannya melayani pelanggan dengan sepenuh hati dengan sesekali bersenda gurau atau mengajak berfoto bersama. Keterkaitan antara pengelolaan makanan lokal dengan berbagai aspek pendukung Gudeg Pawon secara tidak langsung akan memunculkan segmen wisatawan yang loyal dan memiliki motivasi tinggi untuk berkunjung kembali. Oleh karena itu, perlu disadari pengelolaan makanan lokal yang tepat mampu menjaga keberlangsungan dari Gudeg Pawon.

\section{Kesimpulan}

Hasil studi terhadap segmentasi pasar Gudeg Pawon menunjukkan dua tipe utama wisatawan kuliner yakni, Experiencers dan Enjoyers. Kedua tipe ini menjelaskan nilai positif pada makanan lokal sebagai sebuah daya tarik wisata kuliner. Bukan hanya berfokus pada aspek makanan lokalnya, namun modal kultural, serta atmosfer yang ada di Gudeg Pawon merupakan sebuah otentitas yang psikologis seseorang dalam menikmati gudeg Pawon. Segmen wisatawan kuliner Gudeg Pawon menjadi justifikasi terhadap adanya faktor-faktor yang mampu memotivasi wisatawan untuk mengunjungi sebuah destinasi kuliner. Hasil identifikasi terhadap wisatawan kuliner Gudeg Pawon menunjukkan bahwa, motivasi utama dari wisatawan terkait pada faktor pengalaman dan kebaruan pada makanan. Berdasarkan pemahaman akan segmentasi pasar dan faktor- faktor yang memotivasi wisatawan kuliner, pengelolaan 
serius dan mendalam terhadap makanan lokal diharapkan mampu menjadi potensi besar dalam pengembangan destinasi wisata kuliner.

\section{Daftar Pustaka}

Allen, P., \& Hinrichs, C. (2007). Buying into "buy local": Engagements of United States local food initiatives. In D. Maye, L. Holloway, \& M. Kneafsey (Eds.), Alternative food geographies. Annals of the American Association of Geographers. London: Elsevier.

Assauri, S. (2015). Manajemen Pemasaran, Edisi 15. Jakarta: Rajawali Perseda.

Ayustina, R. D. (2019). The Current Practices of Extensive Reading in Literature Class (Descriptive Qualitative Study at the Third Semester Students of English Education Study Program of IAIN Bengkulu in Academic Year 2018/2019). Thesis. English Letters Study program, Islamic Education `and Tadris Faculty.

Björk, P., \& Kauppinen-Räisänen, H. (2016). Local food: A source for destination attraction. International Journal of Contemporary Hospitality Management, 28(1), 177-194. https://doi.org/10.1108/IJCHM-05-2014-0214.

Campelo, A., Aitken, R., Thyne, M., \& Gnoth, J. (2013). Sense of Place: The Importance for Destination Branding. Journal of Travel Research.

Canadian Tourism Commission. (2002). Acquiring A Taste for Cuisine Tourism: A Product Development Strategy.Ottawa: CTC.

Castillo-Canalejo, A. M., Sánchez-Cañizares, S. M., Santos-Roldán, L., \& MuñozFernández, G. A. (2020). Food Markets: A Motivation-Based Segmentation of Tourists. International Journal of Environmental Research and Public Health, 17(7), 2312.

Cho, M., Bonn, M. A., \& Brymer, R. A. (2014). A Constraint-Based Approach to Wine Tourism Market Segmentation. Journal of Hospitality \& Tourism Research, 41(4), 415-444. doi:10.1177/1096348014538049.

Durallia, O. (2017). Culinary Tourism. A New Trend on the Tourism Market. Expert Journal of Marketing, Volume 5, Issue 2, pp.66-71, 2017.

Ellis, A., Park, E., Kim, S., \& Yeoman, I. (2018). What is food tourism?. Tourism Management, 68, 250-263.

Henderson, C. J. (2014). Food and culture: in search of a Singapore cuisine. British Food Journal, Vol. 116 No. 6, pp. 904-917. 
Irianto, A. (2004). Statistik Konsep Dasar dan Aplikasinya. Jakarta: Kencana.

Karim, S. A., \& Chi, C. G. (2010) Culinary Tourism as a Destination Attraction: An Empirical Examination of Destinations' Food Image, Journal of Hospitality Marketing \& Management, 19:6, 531-555, DOI: 10.1080/19368623.2010.493064.

Kotler, P. (2007). Marketing Management. Beijing: Tsinghua University Press.

Kim, Y.G., Eves, A., \& Scarles, C. (2009). Building a model of local food consumption on trips and holidays: A grounded theory approach. International Journal of Hospitality Management, 28, 423-431. https://doi.org/10.1016/j.ijhm.2008.11.005.

Kim, Y. G., \& Eves, A. (2012). Construction and validation of a scale to measure tourist motivation to consume local food. Tourism Management, 33(6), 1458-1467.

Kline, C., Lee, S.J. and Knollenberg, W. (2018), “Segmenting foodies for a foodie destination", Journal of Travel and Tourism Marketing, Vol. 35 No. 9, pp. 12341245.

Leewellyn, V. S., \& Abdillah, F. (2020). Inventarisasi Konsep Ekosistem Pariwisata Dalam Pengembangan Destinasi Wisata Berkelanjutan: Kasus Waduk Walahar, Kabupaten Karawang. Destinesia: Jurnal Hospitaliti dan Pariwisata Vol 1, No. 2, Maret 2020, pp. 57-67. E-ISSN 2686-2042.

Long, L. (2004). Culinary tourism. Lexington, KY: The University Press of Kentucky.

Long, L. (2013). Culinary Tourism. Encyclopedia of Food and Agricultural Ethics. DOI 10.1007/978-94-007-6167-4_416-1.

Mak, A.H.N., Lumbers, M., Eves, A., \& Chang, R.C.Y. (2012). Factors influencing tourist food consumption. International Journal of Hospitality Management, 31, 928-936. https://doi.org/10.1016/j.ijhm.2011.10.012.

Pimentel, J.L. (2019). Some Biases in Likert Scaling Usage and its Correction. International Journal of Sciences: Basic and Applied Research (IJSBAR) (2019) Volume 45, No 1, pp 183-191.

Richards, G. (2005). Gastronomy: An essential ingredient in tourism production and consumption, In Tourism and Gastronomy. A. H. Richards. London: Routledge Taylor \& Group, 3-20.

Sims, R. (2009). Food, place and authenticity: local food and the sustainable tourism experience. Journal of Sustainable Tourism. 17:3, 321-336.

Soecahyadi. (2012). Analaisa Statistik dengan Aplikasi SPSS. - Edisi Pertama Jakarta; Usahid Jakarta. ISBN: 978-602-74689-2-4. 
Sudaryono. (2019). Metodologi Penelitian: Kuantitatif, Kualitatif, dan Mix Method. Ed. 2. Depok: Rajagrafindo Persada.

Sun, S. (2009). An Analysis on the Conditions and Methods of Market Segmentation. International Journal of Business and Management. Vol. 4, No. 2.

Teegavarapu, S., Summers, J. D., \& Mocko, G. M. (2008). Case Study Method for Design Research: A Justification. Proceedings of IDETC/DTM 2008 ASME 2008 International Design Engineering Technical Conferences \& Computers and Information in Engineering Conference. August 3-6, 2008, New York city, New York, USA.

Umar, H. (2013). Metode Penelitian untuk Skripsi dan Tesis. Jakarta: Rajawali.

Wolf, E. (2004). Culinary Tourism: A Tasty Economic Proposition. Portland, OR: International Culinary Tourism Association.

World Tourism Organization. (2017). Affiliate Members Report, Volume sixteen Second Global Report on Gastronomy Tourism. Madrid: UNWTO.

Wijayanti, A. (2020). Wisata Kuliner Sebagai Strategi Penguatan Pariwisata Di Kota Yogyakarta, Indonesia. Khasanah Ilmu : Jurnal Pariwisata Dan Budaya. Volume 11 Nomor 1, Maret 2020 ISSN : 2087-0086 (print), 2655-5433 (online). DOI: $10.31294 /$ khi.v11i1.7998

Yoety, O. A. (2002). Perencanaan Strategis Pemasaran Daerah Tujuan Wisata. Jakarta: Pradnya Paramita.

Yun, D., Hennessey, S.N., \& MacDonald, R. (2011). Understanding Culinary Tourists: Segmentations based on Past Culinary Experiences and Attitudes toward Food-related Behaviour. International CHRIE Conference-Refereed Track.

Internet

Dispar. (2019). Pesona Mudik Yogyakarta 2019. Visiting Jogja Istimewa. di https://visitingjogja.com/18349/pesona-mudik-yogyakarta-2019/ (Diakses tanggal 30 juni 2020).

Hazmi, A. (2017). Menilik Gudeg Pawon Yang Antriannya Selalu Panjang. Good news Indonesia. Di https://www.goodnewsfromindonesia.id/2017/07/31/menilikgudeg-pawon-yang-antriannya-selalu-panjang (Diakses 1 juli 2020).

Reily, M. (2019). Pemerintah Target Wisata Gastronomi Indonesia Masuk Tiga Besar Dunia. Fajrian, H. Hi https://katadata.co.id/berita/2019/04/25/pemerintah-target-wisata-gastronomiindonesia-masuk-tiga-besar-dunia (Diakses tanggal 29 juni 2020). 
Sakti, G. (2019). Siaran Pers : Indonesia Promosikan Kuliner Lokal dalam Forum Dunia "Gastronomy Tourism 2019" di Spanyol. Siaran Pers Kementrian Pariwisata dan Kreatif. Ekonomi di https://www.kemenparekraf.go.id/post/siaran-pers-indonesia-promosikankuliner-lokal-dalam-forum-dunia-gastronomy-tourism-2019-di-spanyol (Diakses tanggal 30 juni 2020).

\section{Profil Penulis}

Ahmadintya Anggit Hanggraito adalah praktisi dan peneliti pariwisata sejak 2017. Dia menyelesaikan studi S1 Administrasi Bisnis Universitas Brawijaya Malang pada tahun 2012, S2 Kajian Pariwisata di Universitas Gadjah mada Yogyakarta pada tahun 2019.

Budiani adalah praktisi dan peneliti di bidang sosial dan Antropologi sejak 2013. Dia menyelesaikan studi S1 Antropologi Universitas Indonesia pada tahun 2013. Untuk saat ini sedang menyelesaikan S2 Kajian Pariwisata di Universitas Gadjah mada Yogyakarta. 